\title{
Methodical Approach to Assessing Food Safety of Ukraine
}

\author{
Iryna Mihus $^{1 *}$ [0000-0001-6939-9097], Mykola Denisenko [0000-0001-8767-9762] \\ 1 "KROK” University, Kyiv, Ukraine \\ ${ }^{2}$ Kyiv National University of Technologies and Design, Kyiv, Ukraine \\ *irynamihus@gmail.com
}

\begin{abstract}
The article discusses the views of scientists on the assessment of Food safety of Ukraine and the threats that affect it. The main indicators on the basis of which the state of food safety of the state is assessed have been systematized. The proposed factors that determine the degree of food safety are divided into those that may have a long-term and shortterm nature of action. It is proposed under the concept of "methodological approach to food safety assessment" to understand a set of methods for assessing the state of food safety at the strategic and tactical levels in order to develop measures to neutralize established and predictable threats. Strategic and tactical indicators of food safety assessment of Ukraine are distinguished, on the basis of which a methodical approach to food safety assessment has been developed. The peculiarity of the proposed methodological approach is the calculation of strategic indicators in two directions: in general, for all types of agricultural products and separately for each type of it; in Ukraine, in certain regions and at individual agricultural enterprises.
\end{abstract}

Keywords: economy, economic security, food safety, threats, methodical approach, strategy, tactics.

\section{INTRODUCTION}

The level of food safety of the state can be estimated, characterizing the following indicators: the state of health of the population, as one of the main conditions that ensures sustainable and progressive development of the state; prolongation of life and demographic situation; availability of a national program for the development of the agro-industrial complex, fisheries and forestry; provision of food to the population; the state of food producing industries; food quality; availability of food to all segments of the population; volumes and opportunities to increase strategic food stocks in case of unforeseen and extraordinary circumstances; state of production and scientific and technical base; opportunities to preserve and improve the habitat.

An adequate scorecard should characterize the state of the main factors of food safety. As the most important factors, it is proposed to consider the following [1, p. 69]:

1) the level and structure of final food intake;
2) state of food potential of agro-industrial complex and natural resources for agricultural purposes;

3) volumes and structure of food export-import in the region, which characterize the interregional aspect of reproduction;

4) food quality and safety.

Today, among domestic researchers there is no single point of view on the system of criteria and indicators that allow to comprehensively characterize the state of the regional agro-industrial complex and the food market in terms of food safety. For the national level, there are generally accepted criteria and indicators of food safety, but within the framework of real work for the level of the region, the task of expanding the range of such indicators and clarifying the criteria taking into account the specifics of the region, the level of ensuring food safety (obviously, the composition of criteria for this level will differ from the national one) $[2$, p. $98 ; 3 ; 4$, p. $158 ; 5$, p. 89].

For the regional level, the requirement to comply with food independence may not be feasible for many 
regions. Moreover, the imperative of achieving food self-sufficiency (for the purpose of ensuring safety) for the regional level, unlike the national level, loses its sharpness.

First, the manifestation of external threats caused by other entities of the same level (other regions) or the socio-economic situation in the country as a whole is generally less likely than the manifestation of threats to national security by other states (struggle for markets, economic blockade, etc.) or world markets.

Secondly, the cycles of regional reproduction of food, possessing the world properties of integral systems, are included as subsystems in the socioeconomic complex of the country, balancing ultimately at the national level. As noted earlier, inter-district economic and social ties play a significant role in the formation of resources that ensure the reproduction process in the region. Exchange of labor products, territorial redistribution of material and financial resources, inter-district migration of the population, information flows - all this causes the open nature of the region's economy as a prerequisite for the efficiency of its economy, based on the territorial division of labor.

\section{RESEARCH METHODOLOGY}

The most important indicator of the level of food safety is the caloric content of the daily diet of the population (and the associated total amount of food per capita), that is, the indicator of the volume of consumption (in strategic or natural equivalent) and its compliance with international norms [6, p. 67]. In our opinion, it is necessary to review and clarify both the composition of the criteria applicable to the assessment of regional food safety and their importance for this level. At the same time, two main points should be reflected: adequate food supply to the population of the region and the possibility of its preservation or improvement in the long term, regardless of internal and external threats. Such a statement of the issue makes it possible to balance regional interests of food availability in the short term and strategic orientation to the sustainable reproduction of the agro-industrial complex of the region, the development of its potential and saturation of the regional food market with its own products.

The most common criteria for ensuring food safety in the region, in our opinion, may be:

1) compliance of the level and structure of final consumption of food with rational physiological norms of healthy eating. This criterion characterizes the economic and physical availability of food to the population of the region;

2) availability of production potential of agricultural sectors sufficient for the production of basic (vital) foodstuffs in volume and assortment, which allows fulfilling the requirement of safe level of regional food export-import. This criterion characterizes the unlimited in time ability of the agroindustrial complex of the region to maintain food supply and guarantee protection against external threats to food safety. The presence and condition of natural resources of agricultural purposes, which serves as a prerequisite for sustainable reproduction in the agroindustrial complex, should also be reflected in this criterion;

3) compliance of the volume and structure of food export-import to a safe level for the region, determined by the possibilities of economically feasible production of basic (vital) foodstuffs in the region. This criterion directly establishes a safe ratio of intraregional production and interregional trade;

4) compliance of food quality and safety with the requirements of sanitary and hygienic environmental and epidemiological standards of healthy eating. This criterion characterizes the requirement of observance of food quality to ensure food safety.

The above criteria should find their expression in a number of indicators that quantify the state of food safety in accordance with these criteria. For each of the main criteria, it is possible to determine a number of indicators, of which one is the most important for the characteristics of food safety according to this criterion. Thus, for the characteristics of a safe import level, the main indicator is the self-reliance coefficient, calculated on a cost or energy basis.

Such indicators can be calculated directly or be complex indicators consisting of several components. As has been shown, factors determining the degree of food safety of the region in modern conditions may have a short-term nature of action. Long-term factors include:

- groups of the population living below the poverty line and do not have sufficient income to purchase a minimum set of food;

- population of territories whose food supply is not provided by market mechanisms due to external factors (for example, transport inaccessibility);

- imbalance of nutrition from certain components, which leads to loss of health of the nation or individual groups of the population;

- low control over food safety, which causes food to become a threat to the life and health of the nation;

- depletion of the natural potential of agricultural production in the country leads to a decrease in the level of food supply to the nation; 
- low material, technical, financial, scientific and technological potential of sustainable reproduction of agricultural sectors.

Short-term factors that pose a potential threat to the food safety of the region include the following:

- instability of agricultural production and the possibility of natural cataclysms that reduce food supply in certain periods;

- great dependence of food supply in the region on external sources against the background of unstable conditions of national and world markets and foreign exchange earnings from imports;

- the unstable foreign policy situation of the country in the world can lead to a trade embargo and other similar sanctions.

The indicators used to assess the level of regional food safety can be both absolute and relative. Absolute indicators (for example, the gross product of agriculture in the region, the cost of a minimum set of food products) are important characteristics of the state of the agro-industrial complex and the food market of the region. However, most of them only allow you to indirectly assess the level of food safety. Therefore, a special role in the food safety scorecard belongs to relative indicators, which makes it possible to determine the level of phenomena that characterize food safety, and to compare the state of food safety in different regions, regardless of interregional differences in structure and level of food production and consumption. At the same time, for a fuller analysis of the food safety of the region, such indicators should be supplemented by the calculation of absolute values.

Determination of the values of these main indicators makes it possible to raise the issue of quantitative characteristics of the level of food safety of the region on the basis of the most general integrated indicator the food safety index of the region. The latter can be calculated as a weighted average value of its indicators, while the index of current and long-term food safety can be calculated using different weight assessments of indicators [3, p. 76]. The analysis of the state of food safety of the region, in accordance with the established criteria, can be carried out in these four directions by detailing and calculating indicators in dynamics for many years, characterizing the current state and trends of changes in this state.

To characterize the state of food consumption in the region, the following indicators can be considered:

1. Composition and structure of the population of the region, which make it possible to identify the share of urban and rural population, the population of working age, pensioners, as well as the expected life expectancy at birth.
2. The size of the subsistence minimum, the cost of the minimum food basket compared to the average monthly salary and social benefits, the average monthly pension. The number of the population with incomes below the subsistence minimum. The share of the population's expenses for the purchase of food in the structure of expenses. Purchasing power of the population.

3. Distribution of cash income in society (decile stratification coefficient, Gini index).

4. Caloric content and structure of the monthly diet, average consumption of basic foods, correlation with rational nutritional standards.

5. Dynamics and level of food prices. Changing the cost of a food basket.

6. Development of food trade infrastructure, retail structure.

To characterize the potential of the agro-industrial complex of the region, it is proposed to use the following indicators:

1. The level and structure of production of the most important types of crop production and livestock and food in dynamics (absolute values and per capita). Crop yield, livestock and poultry productivity.

2. The state of the material and technical base of the agroindustrial complex (fleet of basic types of equipment, wear of fixed assets of the processing industry, investments in agroindustrial complex). Indicators of fund-, mechano-, energy-armed agricultural and processing enterprises.

3. The share of agriculture in the gross regional product.

4. Index of prices for agricultural and industrial products (price disparity).

5. The share of agricultural producers' expenses.

6 . The state of social infrastructure of the village.

7. Size of state support for the agricultural sector.

8. Indicators of the formation of the regional food fund.

9. Availability and condition of natural resources of agricultural purposes (area of agricultural land, fertilization, erosion processes).

10. Financial condition of agricultural enterprises.

To characterize food export-import in the region, the following indicators are analyzed:

1. Import and export of food products.

2. Self-sufficiency of food (the share of imported food and food imported from other regions, in the final 
consumption of the region) by the main types of food products.

3. Relations of food consumption per capita due to regional production to rational consumption standards for basic types of food.

To assess the quality of food in the region, it is possible to use the following indicators:

1. Volumes of detected food products that do not meet the quality requirements.

2. The content of harmful substances in inspected products.

3. The ratio of the number of products rejected by the control bodies to the total number of inspected products.

To characterize the food independence of the region in real conditions, you can use the modified first method, while the calculations take into account not all food produced and consumed in the region, but only those that are part of the main (vital) products. Such products are understood as food products that are traditionally produced not in Ukraine and are the basis of the food market of the population in structure and volume.

The use of the generally accepted limit value of the level of food independence of $20 \%$ for the characteristics of the state of food safety of the region can be justified only for the regions developed in agricultural respect, having sufficient bioclimatic potential for the production of all other food products. In other cases, safe levels should be calculated for each food group, taking into account the possibility of economically feasible production of products of this group in the region and the presence of sustainable interregional relations within Ukraine for the import of this group.

The most difficult is the quantitative assessment of food quality, since the results of the inconsistencies in the content in food hazardous substances in food by normative consumption or non-compliance of products with established standards can be used to assess the quality of all food products only with a certain degree of error. At the same time, the most applicable indicator (although it characterizes the overall quality of food only indirectly) can be recognized as the ratio of the number of products recognized by the control bodies to the corresponding quality requirements to the total number of products inspected.

Calculated on the basis of the described method, the food safety index of the region allows to characterize the level of food safety in order to analyze the dynamics of its change and compare regions at this level. The disadvantage of this indicator is a certain conditionality of determining the security or insecurity of food safety of the region on its basis (it is obvious that the higher the indicator, the better the state of regional food safety). Since in the world scientific practice to assess the provision of food safety the most widespread thresholds of the main components of its factors, it is advisable to supplement the indicator with a number of indicators for which such thresholds are set.

The thresholds of food safety factors are determined depending on the national demographic and socioeconomic characteristics of each region, while as factors it is possible to take differentiation of income and consumption, average consumption of protein of animal and vegetable origin, poverty and poverty, degradation of person and family, increase in mortality, in particular children's, level of average life expectancy.

The final conclusion on the state of regional food safety can be made only on the basis of a comprehensive analysis of the entire set of indicators of the socio-economic state of households, the state of the food market, all areas of the agro-industrial complex and natural resources of agricultural purposes of the region, as well as interregional and foreign trade.

On the basis of identifying problem areas (for which the values of calculated indicators are the lowest) the priority directions of state regulation should be formulaized, the goals and methods of their achievement within the framework of the system of ensuring food safety of the region should be determined. Thus, the analysis of indicators used to characterize the state of food safety is an objective basis for the formation of a strategy and tactics for its provision.

Assessing the current state of food safety, you can distinguish a number of positive characteristics, namely:

- the formation of market infrastructure (the system of wholesale food markets and marketing information);

- growth of incomes of the population;

- increasing the self-sufficiency of the population with food due to the expansion of the size of households and suburban areas.

However, there are also negative characteristics, in particular:

- a decrease in the purchasing power of the population;

- imperfect state regulation of foreign trade in food;

- there are no conditions for the stable functioning of the food market;

- conditions for stable growth of production volumes of basic types of agricultural products have not been created. 


\section{RESEARCH RESULTS}

On the basis of the study, a methodical approach to the assessment of food safety was proposed. The concept of "methodological approach to food safety assessment" should be understood as a set of methods for assessing the state of food safety at the strategic and tactical levels in order to develop measures to neutralize established and predictable threats. In order to improve the methodology for assessing food safety of the state, it is proposed to amend the indicators by which its calculation is carried out in the Methodology for determining the main indicators of food safety [7] and methodological recommendations for calculating the level of economic security of Ukraine [8] by aligning them with each other and dividing the assessment indicators into strategic and tactical indicators (Table 1).

It has been proved that the division of indicators into strategic and tactical is expedient due to differences both in threats affecting the state of food safety and in the ways of their neutralization.

The accumulation of received information is carried out according to both groups of indicators over the past year, as well as by strategic indicators over the past five years, which will contribute to determining the trend of food safety of our country and developing measures to neutralize various threats. After determining the strategic indicators, they have been compared in recent years according to the following parameters: "negative dynamics" - 0 points, "no dynamics" - 1 point and "positive dynamics" - 2 points. The amount of points received allows you to determine the "indicator of strategic food safety" by the formula:

$$
\mathrm{SFS}=\sum \mathrm{S}_{\mathrm{i}},(1)
$$

where SFS is an indicator of strategic food safety, $S_{i}$ is the 1st indicator of strategic food safety.

The peculiarity of the proposed methodology for assessing food safety is the calculation of strategic indicators in two directions:

1) in general for all types of agricultural products and separately for each type of agricultural products;

2) in General in Ukraine, in certain regions and at individual agricultural enterprises.

The results of the analysis of tactical indicators of food safety are compared with world standards and are evaluated according to the following parameters: "lower than international standards" - 0 points, "complies with international standards" - 1 point and "higher than international standards" - 2 points. By the amount of points received, the "indicator of tactical food safety" is determined by the formula: where TFS is an indicator of tactical food safety, $T_{i}$ is the first indicator of tactical food safety.

Table 1. Strategic and tactical assessment indicators food safety of Ukraine

\begin{tabular}{|c|c|}
\hline Strategic indicators & Tactical indicators \\
\hline $\begin{array}{l}\text { 1. GDP dynamics per capita, } \% \\
\left(\mathrm{~S}_{1}\right)\end{array}$ & $\begin{array}{l}\text { 1. Daily caloric content of } \\
\text { human nutrition }\left(\mathrm{T}_{1}\right)\end{array}$ \\
\hline $\begin{array}{l}\text { 2. Purchasing power dynamics, } \\
\%\left(\mathrm{~S}_{2}\right)\end{array}$ & $\begin{array}{l}\text { 2. Consumption of meat and } \\
\text { meat products (per year/person) } \\
\left(\mathrm{T}_{2}\right)\end{array}$ \\
\hline $\begin{array}{l}\text { 3. Per capita dynamics of } \\
\text { agricultural products, } \%\left(\mathrm{~S}_{3}\right)\end{array}$ & $\begin{array}{l}\text { 3. Consumption of milk and } \\
\text { dairy products (per year/person) } \\
\left(\mathrm{T}_{3}\right)\end{array}$ \\
\hline $\begin{array}{l}\text { 4. Dynamics of the number of } \\
\text { agricultural enterprises, } \%\left(\mathrm{~S}_{4}\right)\end{array}$ & $\begin{array}{l}\text { 4. Egg consumption (per } \\
\text { year/person) }\left(\mathrm{T}_{4}\right)\end{array}$ \\
\hline 5. Dynamics of acreage, $\%\left(\mathrm{~S}_{5}\right)$ & $\begin{array}{l}\text { 5. Fish consumption (per } \\
\text { year/person) }\left(\mathrm{T}_{5}\right)\end{array}$ \\
\hline $\begin{array}{l}\text { 6. Yield dynamics } \\
\text { agricultural crops, } \%\left(\mathrm{~S}_{6}\right)\end{array}$ & $\begin{array}{l}\text { 6. Sugar intake (per year/person) } \\
\left(\mathrm{T}_{6}\right)\end{array}$ \\
\hline 7. Livestock dynamics, $\%\left(\mathrm{~S}_{7}\right)$ & $\begin{array}{l}\text { 7. Consumption of oil and other } \\
\text { vegetable fats (per year/person) } \\
\left(\mathrm{T}_{7}\right)\end{array}$ \\
\hline 8. Dynamics of poultry, $\%\left(\mathrm{~S}_{8}\right)$ & $\begin{array}{l}\text { 8. Consumption of potatoes (per } \\
\text { year/person) }\left(T_{8}\right)\end{array}$ \\
\hline $\begin{array}{l}\text { 9. Dynamics of fishing/fishing } \\
\text { ratio, } \%\left(\mathrm{~S}_{9}\right)\end{array}$ & $\begin{array}{l}\text { 9. Consumption of vegetables } \\
\text { and } \\
\text { (per year/person) }\left(\mathrm{T}_{9}\right)\end{array}$ \\
\hline $\begin{array}{l}\text { 10. Dynamics of productivity in } \\
\text { agricultural enterprises, } \%\left(\mathrm{~S}_{10}\right)\end{array}$ & $\begin{array}{l}\text { 10. Consumption of fruits, } \\
\text { berries, nuts and grapes (per } \\
\text { year/person) }\left(\mathrm{T}_{10}\right)\end{array}$ \\
\hline $\begin{array}{l}\text { 11. Price dynamics for certain } \\
\text { types of agricultural products, } \\
\%\left(S_{11}\right)\end{array}$ & $\begin{array}{l}\text { 11. Consumption of bread and } \\
\text { bread products } \\
\text { year/person)( }\left(T_{11}\right)\end{array}$ \\
\hline $\begin{array}{l}\text { 12. Dynamics of the ratio of } \\
\text { equity and attracted capital of } \\
\text { agricultural enterprises, } \%\left(\mathrm{~S}_{12}\right)\end{array}$ & $\begin{array}{l}\text { 12. Production of milk and dairy } \\
\text { products (per year/person) }\left(T_{12}\right)\end{array}$ \\
\hline $\begin{array}{l}\text { 13. Dynamics of profitability of } \\
\text { agricultural enterprises, } \%\left(\mathrm{~S}_{13}\right)\end{array}$ & $\begin{array}{l}\text { 13. Grain production (per } \\
\text { year/person) }\left(\mathrm{T}_{13}\right)\end{array}$ \\
\hline $\begin{array}{l}\text { 14. Dynamics of the ratio of } \\
\text { issued bank loans to agricultural } \\
\text { enterprises, } \%\left(\mathrm{~S}_{14}\right)\end{array}$ & $\begin{array}{l}\text { 14. Vegetable production (per } \\
\text { year/person) }\left(\mathrm{T}_{14}\right)\end{array}$ \\
\hline $\begin{array}{l}\text { 15. Dynamics of the ratio of } \\
\text { outstanding bank loans to } \\
\text { agricultural enterprises, } \%\left(\mathrm{~S}_{15}\right)\end{array}$ & $\begin{array}{l}\text { 15. Production of meat and meat } \\
\text { products (per year/person) }\left(T_{15}\right)\end{array}$ \\
\hline
\end{tabular}

Source: author's development

The general food safety indicator is defined as the sum of the two indicators above:

$$
\mathrm{CFS}=\mathrm{SFS}+\mathrm{TFS}=\sum \mathrm{T}_{\mathrm{i}}+\sum \mathrm{S}_{\mathrm{i}}
$$

where SFS is the general indicator of food safety.

The results of certain indicators are evaluated according to the criteria that allow you to set a "general food safety indicator" (Table 2).

$$
\mathrm{TFS}=\sum \mathrm{T}_{\mathrm{i}},(2)
$$


Table 2 Criteria for determining the "general indicator of food safety"

\begin{tabular}{|c|c|c|c|}
\hline \multirow{2}{*}{ Indicator Name } & \multicolumn{3}{|c|}{ The value and state of food safety } \\
\cline { 2 - 4 } & $\begin{array}{c}\text { Crisis } \\
\text { State }\end{array}$ & $\begin{array}{c}\text { Pre-crisis } \\
\text { state }\end{array}$ & $\begin{array}{c}\text { Normal } \\
\text { State }\end{array}$ \\
\hline $\begin{array}{c}\text { Strategic food } \\
\text { safety indicator }\end{array}$ & $0-10$ & $11-20$ & $21-30$ \\
\hline $\begin{array}{c}\text { Tactical food safety } \\
\text { indicator food }\end{array}$ & $0-10$ & $11-20$ & $21-30$ \\
\hline $\begin{array}{c}\text { General } \\
\text { safety indicator }\end{array}$ & $\mathbf{0 - 2 0}$ & $\mathbf{2 1 - 4 0}$ & $\mathbf{4 1 - 6 0}$ \\
\hline
\end{tabular}

Source: author's development

\section{RESULTS AND DISCUSSION}

Using the results of the research conducted in the second section of the dissertation and the proposed methodological approach, we will conduct an assessment of the state of food safety of Ukraine (Table $3-4)$.

Table 3. Results of food safety assessment of Ukraine based on strategic indicators

\begin{tabular}{|c|c|c|}
\hline Strategic indicators & $\begin{array}{l}\text { Change } \\
\text { Type }\end{array}$ & $\begin{array}{l}\text { Metric } \\
\text { Value }\end{array}$ \\
\hline 1. GDP dynamics per capita, $\%\left(S_{1}\right)$ & Reduce & 0 \\
\hline 2. Purchasing power dynamics, $\%\left(S_{2}\right)$ & Reduce & 0 \\
\hline $\begin{array}{l}\text { 3. Per capita dynamics of agricultural } \\
\text { products, } \%\left(\mathrm{~S}_{3}\right)\end{array}$ & Reduce & 0 \\
\hline $\begin{array}{l}\text { 4. Dynamics of the number of } \\
\text { agricultural enterprises, } \%\left(\mathrm{~S}_{4}\right)\end{array}$ & Increase & 2 \\
\hline 5. Dynamics of acreage, $\%\left(\mathrm{~S}_{5}\right)$ & Reduce & 0 \\
\hline $\begin{array}{l}\text { 6. Yield dynamics of agricultural crops, } \\
\%\left(\mathrm{~S}_{6}\right)\end{array}$ & Reduce & 0 \\
\hline 7. Livestock dynamics, $\%\left(\mathrm{~S}_{7}\right)$ & Reduce & 0 \\
\hline 8. Dynamics of poultry, $\%\left(\mathrm{~S}_{8}\right)$ & Reduce & 0 \\
\hline $\begin{array}{l}\text { 9. Dynamics of fishing/fishing ratio, \% } \\
\left(\mathrm{S}_{9}\right)\end{array}$ & Increase & 2 \\
\hline $\begin{array}{l}\text { 10. Dynamics of productivity in } \\
\text { agricultural enterprises, } \%\left(\mathrm{~S}_{10}\right)\end{array}$ & Increase & 2 \\
\hline $\begin{array}{l}\text { 11. Price dynamics for certain types of } \\
\text { agricultural products, } \%\left(S_{11}\right)\end{array}$ & Increase & 2 \\
\hline $\begin{array}{l}\text { 12. Dynamics of the ratio of equity and } \\
\text { attracted capital of agricultural } \\
\text { enterprises, } \%\left(S_{12}\right)\end{array}$ & Increase & 2 \\
\hline $\begin{array}{l}\text { 13. Dynamics of profitability of } \\
\text { agricultural enterprises, } \%\left(S_{13}\right)\end{array}$ & Increase & 2 \\
\hline
\end{tabular}

\begin{tabular}{|l|l|c|}
$\begin{array}{l}\text { 14. Dynamics of the ratio of issued bank } \\
\text { loans to agricultural enterprises, \% }\left(\mathrm{S}_{14}\right)\end{array}$ & Reduce & 0 \\
\hline $\begin{array}{l}\text { 15. Dynamics of the ratio of } \\
\text { outstanding bank loans to agricultural } \\
\text { enterprises, \% }\left(\mathrm{S}_{15}\right)\end{array}$ & Reduce & 0 \\
\hline Strategic Food safety Indicator (SFS) & & $\mathbf{1 2}$ \\
\hline
\end{tabular}

Source: author's development

The results of the assessment of Food safety of Ukraine on the basis of strategic indicators indicated "pre-crisis state", which is confirmed by preliminary calculations.

Table 4. Results of food safety assessment of Ukraine based on tactical indicators

\begin{tabular}{|c|c|c|}
\hline Tactical indicators & $\begin{array}{l}\text { Change } \\
\text { Type }\end{array}$ & $\begin{array}{l}\text { Metric } \\
\text { Value }\end{array}$ \\
\hline $\begin{array}{l}\text { 1. Daily caloric content of human nutrition } \\
\left(\mathrm{T}_{1}\right)\end{array}$ & Reduce & 0 \\
\hline $\begin{array}{l}\text { 2. Consumption of meat and meat products } \\
\text { (per year/person) }\left(\mathrm{T}_{2}\right)\end{array}$ & Reduce & 0 \\
\hline $\begin{array}{l}\text { 3. Consumption of milk and dairy products } \\
\text { (per year/person) }\left(\mathrm{T}_{3}\right)\end{array}$ & Reduce & 0 \\
\hline 4. Egg consumption (per year/person) $\left(\mathrm{T}_{4}\right)$ & Reduce & 0 \\
\hline 5. Fish consumption (per year/person) $\left(\mathrm{T}_{5}\right)$ & Reduce & 0 \\
\hline 6. Sugar intake (per year/person) $\left(\mathrm{T}_{6}\right)$ & Reduce & 0 \\
\hline $\begin{array}{l}\text { 7. Consumption of oil and other vegetable } \\
\text { fats (per year/person) }\left(\mathrm{T}_{7}\right)\end{array}$ & Reduce & 0 \\
\hline $\begin{array}{l}\text { 8. Consumption of potatoes (per } \\
\text { year/person) }\left(\mathrm{T}_{8}\right)\end{array}$ & $\begin{array}{l}\text { unchan } \\
\text { ged }\end{array}$ & 1 \\
\hline $\begin{array}{l}\text { 9. Consumption of vegetables and melons } \\
\text { (per year/person) }\left(\mathrm{T}_{9}\right)\end{array}$ & $\begin{array}{l}\text { unchan } \\
\text { ged }\end{array}$ & 1 \\
\hline $\begin{array}{l}10 \text { Consumption of fruits, berries, nuts and } \\
\text { grapes (per year/person) }\left(T_{10}\right)\end{array}$ & $\begin{array}{l}\text { unchan } \\
\text { ged }\end{array}$ & 1 \\
\hline $\begin{array}{l}\text { 11. Consumption of bread and bread } \\
\text { products (per year/person })\left(\mathrm{T}_{11}\right)\end{array}$ & $\begin{array}{c}\text { Increas } \\
\mathrm{e}\end{array}$ & 2 \\
\hline $\begin{array}{l}\text { 12. Production of milk and dairy products } \\
\text { (per year/person) }\left(\mathrm{T}_{12}\right)\end{array}$ & Reduce & 0 \\
\hline 13. Grain production (per year/person) $\left(\mathrm{T}_{13}\right)$ & $\begin{array}{c}\text { Increas } \\
\mathrm{e}\end{array}$ & 2 \\
\hline $\begin{array}{l}\text { 14. Vegetable production (per year/person) } \\
\left(\mathrm{T}_{14}\right)\end{array}$ & Reduce & 0 \\
\hline $\begin{array}{l}\text { 15. Production of meat and meat products } \\
\text { (per year/person) }\left(\mathrm{T}_{15}\right)\end{array}$ & $\begin{array}{c}\text { Increas } \\
\mathrm{e}\end{array}$ & 2 \\
\hline Tactical Food safety Indicator (TFS) & & 9 \\
\hline
\end{tabular}

Source: author's development 
The results of Ukraine's food safety assessment based on tactical indicators indicated a "state of crisis."

$$
\mathrm{CFS}=\mathrm{SFS}+\mathrm{TFS}=12+9=21(4)
$$

Thus, the results of the calculation of the general indicator of food safety indicate that Ukraine is in a precrisis state of food safety, the direct impact of which is worsening the financial condition of agricultural enterprises, including due to lack of financial resources.

The use of the proposed methodology will contribute to a more thorough study of the state of food safety, taking into account the tasks envisaged by the mechanism of strengthening ukraine's food safety through financial support of agricultural enterprises.

\section{CONCLUSIONS}

According to the results of the study, it is advisable to draw the following conclusions:

1. The article systematized the main indicators on the basis of which the state of food safety of the state is assessed.

2. A methodical approach to the assessment of food safety was proposed, which is to understandthe set of methods for assessing the state of food safety at the strategic and tactical levels in order to develop measures to neutralize established and predictable threats.

3. It was established that thespecificity of the proposed methodological approach is the calculation of strategic indicators in two directions: in general, for all types of agricultural products and separately for each type of it; ingeneral, in Ukraine, in some regions and at individual agricultural enterprises.

\section{REFERENCES}

[1] Vlasov, V.I. (2001) Hlobalna prodovolcha problema [Global food problem], Kyiv, Ukraine, $506 \mathrm{p}$.

[2] Vorotin, V.Ye. (2002), Makroekonomichne rehuliuvannia $v$ umovakh hlobalnykh transformatsii [Macroeconomic regulation in the context of global transformations], UADU, Kyiv, Ukraine, 392 p.

[3] Hubskyi, B.V. (2006), "Internal and external factors of economic security of Ukraine", Stratehichna panorama, № 1-2, pp. 75-79.

[4] Diehtiar, A.O. (2004), Derzhavno-upravlinski rishennia: informatsiino-analitychne ta orhanizatsiine zabezpechennia [Public administration decisions: information-analytical and organizational support], KhRIDU NADU "Mahistr", Kharkiv, Ukraine, 224 p.
[5] Mostovyi, H.I. (2002), Ahrobiznes : derzhavne rehuliuvannia [Agribusiness: government regulation], Osnova, Kharkiv, Ukraine, 300 p.

[6] Borshchevskyi, P. and Deineko, L. (2007), "Food security of the country: state and tendencies", Rozbudova derzhavy, № 16, pp. 66-73.

[7] Cabinet of Ministers of Ukraine (2007), "Methods for determining the main indicators of food security", available at: https://www.kmu.gov.ua/npas/99719937.

[8] The Verkhovna Rada of Ukraine (2013), The Law of Ukraine "About the statement of Methodical recommendations concerning calculation of level of economic safety of Ukraine", available at: https://zakon.rada.gov.ua/rada/show/v127773113\#Text.

[9] Budoor Salem Edhah and Aasim Zafar (2016), "Enterprise Architecture: A Tool for IS Strategy Formulation”, International Journal of Education and Management Engineering, №2, pp. 14-23. DOI: $10.5815 / \mathrm{ijeme} .2016 .02 .02$.

[10] Hongshun, Su (2012), "Study on Effect Theory of Price Changes with MathCAD", International Journal of Education and Management Engineering(IJEME), №7, pp. 9-15. DOI: 10.5815/ijeme.2012.07.02.

[11] Saqaeeyan, S. and Rismantab, A. (2015), “A Novel Method in Food Safety Management by Using Case Base Reasoning Method", International Journal of Education and Management Engineering, №10, pp. 48-54. DOI: 10.5815/ijisa.2015.10.06.

[12] Ding, Jianjun and Wang, Xihua (2011), "Food Safety Testing Technology Based on The Spectrophotometer and ARM", International Journal of Intelligent Systems and Applications, №10, pp. 48-54. DOI: 10.5815/ijeme.2011.01.08. 